\title{
PERSPEKTIF GENDER DALAM NOVEL KAPAK KARYA DEWI LINGGARSARI ${ }^{1}$ \\ Gender Perspective in Dewi Linggarsari's Kapak
}

\author{
Fitria \\ Kantor Bahasa Provinsi Jambi, Jalan Arif Rahman Hakim No.101, Telanaipura, Jambi \\ Pos-el : fitria_ds@ymail.com
}

(Makalah Diterima Tanggal 1 September 2014-Disetujui Tanggal 28 Oktober 2014)

\begin{abstract}
Abstrak: Tulisan ini mengkaji perspektif gender yang terdapat dalam novel Kapak (2005) karya Dewi Linggarsari dengan menggunakan kritik sastra feminis. Perspektif gender yang ditemukan adalah adanya ketidakadilan dan kesetaraaan gender yang dialami tokoh wanita Mika, Yemnen, dan dokter Astrid. Ketidakadilan gender terlihat saat wanita dianggap sebagai makhluk yang lemah, yang menyebabkan terjadinya subordinasi dan kekerasan. Sementara itu, kesetaraan gender terlihat dari adanya persamaan hak bagi kaum wanita dengan adanya aturan adat yang melindungi wanita dan pendidikan bagi wanita. Wanita bukanlah makhluk lemah yang hanya dijadikan korban kekerasan laki-laki, melainkan makhlukyang kuat dan pemberani serta mampu membantu memperbaiki nasib kaum wanita yang menjadi korban kekerasan suaminya.
\end{abstract}

Kata-Kata Kunci: ketidakadilan gender, kesetaraan gender, subordinasi, kekerasan, pendidikan

Abstract: This research aims to analyze the gender perspective in Kapak, written by Dewi Linggarsari, by using feminist literary criticism.The gender perspective found in this novel is about the existence of both gender inequality and equality experienced by the female characters, i.e. Mika, Yemnen, and dr. Astrid. The gender inequality is obvious when women are considered as weak human beings; it causes subordination and violence. Meanwhile, gender equality can be found in women's struggle against the oppression through custom rules and education. By having good education, women can fight against gender inequality in their environment. This proves that women are not weak human beings who always become the subjects of men's violence. They can even give contributions and benefits to their surroundings or help other women who are being the victims of their husbands' violence.

Key Words: gender inequality, gender equality, subordination, violence, education

\section{PENDAHULUAN}

Seorang pengarang akan memuat beragam persoalan sosial dalam karya yang ditulisnya yang tidak lepas dari kehidupan sekelilingnya. Pengarang wanita juga akan menceritakan gambaran yang jelas dan lengkap mengenai masalah sosial, terutama masalah wanita yang terjadi di sekelilingnya. Masalah sosial yang sering disuarakan seorang pengarang wanita adalah isu gender dan kekerasan terhadap perempuan. Salah satu pengarang wanita yang menuliskan isu tentang gender adalah Dewi Linggarsari.

Dewi Linggarsari merupakan pengarang keturunan Jawa yang sekarang tinggal dan bekerja di Kota Agats, Kabupaten Asmat, Provinsi Papua. Pendidikan tinggi diselesaikannya di jurusan Antropologi, Universitas Gadjah Mada, Yogyakarta tahun 1993. Semenjak mahasiswa, Dewi sudah aktif di dunia kepenulisan dan pernah menjadi asisten peneliti di Pusat Studi Pedesaan dan Kawasan UGM. Setelah berkeluarga, Dewi hijrah 
ke tanah Papua tepatnya di Kota Agats, Kabupaten Asmat, Papua. Semenjak itulah Dewi tertarik menuliskan kehidupan wanita Papua di sekitarnya. Diungkapkan Linggarsari (dalam tabloid Jubi, 16 Februari 2009, hlm. 15) bahwa perempuan Asmat hingga kini masih dipandang hanya bertugas sebatas bekerja di dapur, mengandung, melahirkan, menjaga, serta membesarkan anak. Selain itu, penindasan juga dirasakan kaum wanitanya, yaitu berupa perlakuan kasar dari kaum laki-laki jika keinginannya tidak terpenuhi seperti kalah berjudi dan mabuk-mabukan. Laki-laki tidak segan menampar dan memukul istrinya sendiri. Linggarsari (2004:14) juga mengatakan dengan berlindung di balik mitos dan nilai-nilai adat, perempuan Asmat dipaksa untuk menanggung seluruh beban keluarga dan adat. Dalam keadaan sakit pun seorang perempuan Asmat masih harus menerobos hutan untuk mengambil sagu, sebab tanpa itu keluarga tidak akan makan karena kaum laki-laki pun tidak mau turun tangan. Selain itu, mereka seringkali mendapatkan kekerasan fisik dari suami mereka.

Berdasarkan peristiwa-peristiwa yang dialami oleh wanita Asmat di sekelilingnya itulah, Dewi Linggarsari menulis novel Kapak (2005), Sali (2007), dan Istana Pasir (2010). Di antara novel-novelnya itu, isu gender yang mendapat sorotan tajam ditemukan dalam novelnya yang berjudul Kapak. Novel Kapak, yang diterbitkan kali pertama pada tahun 2005 oleh penerbit Kunci Ilmu Yogyakarta ini, diadaptasi dari kehidupan sosial yang terjadi pada wanita Asmat.

Novel ini menggambarkan bentukbentuk kekerasan kaum lelaki Asmat kepada kaum perempuan. Ini menggambarkan masih adanya masyarakat patriarkat dalam masyarakat Papua. Kekerasan pada wanita tidak hanya terjadi pada masyarakat di wilayah Asmat Papua, tetapi juga di banyak daerah di dunia, khususnya pada masyarakat patriarkat yang cenderung mensubordinasikan kaum perempuan di ranah publik yang menjadikan perempuan begitu rentan terhadap ketidakadilan gender. Selain itu, novel ini juga mengungkapkan pembebasan kaum wanita dari kebodohan, kemiskinan, dan penindasan kaum lakilaki. Ini merupakan salah satu bentuk perjuangan kaum feminis untuk memperjuangkan haknya agar setara dan sejajar dengan kaum laki-laki. Sepengetahuan penulis, belum ada yang melakukan penelitian perspektif gender dalam novel Kapak karya Dewi Linggarsari ini.

Berdasarkan latar belakang tersebut, masalah yang menjadi fokus untuk dibahas pada tulisan ini adalah apa saja bentuk-bentuk perspektif gender yang terdapat dalam novel Kapak karya Dewi Linggarsari? Tujuan yang ingin dicapai dalam penelitian ini adalah menemukan dan menjelaskan bentuk-bentuk perspektif gender yang terdapat dalam novel Kapak karya Dewi Linggarsari.

\section{TEORI \\ Kritik Sastra Feminis}

Konsep feminis ini merupakan fenomena budaya yang sudah berlangsung semenjak abad ke-18 dan mulai gencar setelah ditetapkannya Deklarasi Hak-hak Azasi Manusia PBB pada tahun 1948. Gerakan feminis menginginkan persamaan hak antara laki-laki dan perempuan di semua bidang. Feminis menolak ketidakadilan masyarakat patriarkat yang mendudukkan perempuan dalam posisi inferior dan laki-laki berada pada posisi superior.

Sementara itu dalam ilmu sastra, feminis berhubungan dengan konsep kritik sastra feminis, yaitu sebuah studi sastra yang mengarahkan fokus analisisnya pada perempuan (Showalter dalam Sugihastuti, 2005:18). Sasaran penting dalam kritik sastra feminis ini menurut Endraswara (2008:146) adalah (1) 
mengungkap karya-karya penulis masa lalu dan masa kini; (2) mengungkap berbagai tekanan pada tokoh wanita dalam karya sastra yang ditulis oleh pengarang pria; (3) mengungkap ideologi pengarang wanita dan pria, bagaimana mereka memandang diri sendiri dalam kehidupan nyata; (4) mengkaji aspek ginokritik, memahami proses kreatif kaum feminis; dan (5) mengungkap aspek psikonalisis feminis, mengapa wanita lebih suka hal yang halus, emosional, penuh kasih, dan sebagainya.

Salah satu konsep dasar yang digunakan dalam kritik sastra feminis adalah konsep gender. Konsep gender pertama kali diperkenalkan oleh Rebert Stollen (dalam Nugroho, 2008:2-3) untuk memisahkan pencirian manusia yang didasarkan pada pendefinisian yang bersifat sosial budaya dengan pendefinisian yang berasal dari ciri-ciri fisik biologis. Fakih (2013:7-9) mengatakan bahwa gender adalah semua hal yang dapat dipertukarkan antara sifat perempuan dan lakilaki, yang bisa berubah dari waktu ke waktu serta berbeda dari tempat ke tempat lainnya, maupun berbeda dari suatu kelas ke kelas yang lain. David Graddon dan Joan Swann (dalam Prambudi, 2011:12) menjelaskan bahwa gender lebih banyak digunakan dalam pengertian sehari-hari untuk menyebut pembedaan sosial antara maskulin dan feminin. Konsep gender ini lebih berkonsentrasi pada sifat yang melekat pada laki-laki ataupun perempuan yang dibentuk oleh faktor sosial, budaya, psikologis, dan faktor nonbiologis lainnya. Oleh karena itu, dapat dikatakan bahwa gender diartikan sebagai konsep sosial yang membedakan (dalam arti: memilih atau memisahkan) peran antara laki-laki dan perempuan.

Gender bukanlah kodrat yang dimiliki oleh manusia semenjak lahir, tetapi dikonstruksi oleh lingkungan sosial dan budaya. Gender berbeda pada suatu masyarakat dengan masyarakat lainnya. Sehubungan dengan hal itu, Sugihastuti (2007:4) berpendapat bahwa gender adalah pembagian manusia menjadi lakilaki (maskulin) dan perempuan (feminin) berdasarkan konstruksi sosial budaya. Gender bukanlah sesuatu yang kita dapatkan semenjak lahir dan bukan juga sesuatu yang kita miliki, melainkan sesuatu yang kita lakukan.

Gender adalah perbedaan perilaku (behavioral differences) antara laki-laki dan perempuan yang dikonstruksi secara sosial, yakni perbedaan yang diciptakan oleh manusia melalui proses sosial dan kultural yang panjang, bukan karena perbedaan biologis. Oleh karena itu, gender dapat berubah dari waktu ke waktu, dari tempat ke tempat dan dari kelas ke kelas serta merupakan sesuatu yang kita lakukan.

Konsep gender ini terus berkembang seperti diungkapkan Hubies (dalam Ashori, 1997:25) yang meliputi; (1) gender difference, yaitu perbedaan-perbedaan karakter, perilaku, harapan yang dirumuskan untuk tiap-tiap orang menurut jenis kelamin; (2) gender gap, yaitu perbedaan dalam hubungan berpolitik dan bersikap antara laki-laki dan perempuan; (3) genderization, yaitu acuan konsep penempatan jenis kelamin pada identitas diri dan pandangan orang lain; (4) gender identity, perilaku yang seharusnya dimiliki seseorang menurut jenis kelaminnya; dan (5) gender role, yaitu peran perempuan dan peran laki-laki yang diterapkan dalam bentuk nyata menurut budaya setempat yang dianut.

Problem gender meliputi peran gender, kesetaraan gender, dan ketidakadilan gender. Anshori (1997:24) mengatakan bahwa ketidakadilan gender diidentifikasi melalui berbagai manifestasi ketidakadilan. Manifestasi ketidakadilan yang sering terjadi, antara lain sebagai berikut. (1) Penomorduaan (subordinasi). Pandangan ini menempatkan 
perempuan dalam posisi tidak penting. Perempuan dianggap tidak dapat memimpin karena irasional atau emosional. Fakih (2013:16) mengatakan bahwa pandangan itu menganggap perempuan hanya bisa melakukan pekerjaan rumah tangga karena posisinya sebagai ibu dari anak-anak dan sebagai istri dari seorang suami; (2) Pelabelan negatif (stereotype); (3) Peminggiran; (4) Beban kerja berlebih/multibeban (double burden); dan (5) Kekerasan (violence). Bentuk kekerasan ini dapat bermacam-macam mulai dari bentuk kekerasan fisik, psikis, seksual, hingga ekonomi, baik itu di ruang-ruang keluarga (kekerasan dalam rumah tangga), oleh suami, tetangga, atau saudara, maupun di ruang publik oleh kultur, adat, masyarakat, dan politik. Kekerasan fisik dapat berupa perkosaan, pemukulan, dan penyiksaan, sedangkan kekerasan psikologis dapat berupa pelecehan seksual dan ancaman yang mengusik emosi.

\section{METODE}

Penelitian ini merupakan penelitian deskriptif yang menggunakan metode kualitatif. Metode kualitatif adalah prosedur penelitian yang berdasarkan dan menghasilkan data-data deskriptif berupa data tertulis (Bogdan dan Taylor dalam Moleong, 2002:3). Sumber data penelitian ini adalah novel Kapak karya Dewi Linggarsari, diterbitkan pada tahun 2005 oleh penerbit Kunci Ilmu, Yogyakarta. Pengumpulan data primer dan data sekunder dilakukan dengan metode studi kepustakaan. Data primer penelitian ini adalah novel Kapak karya Dewi Linggarsari, sedangkan data sekunder meliputi buku-buku, artikel ilmiah, dan laporan penelitian tentang kajian gender yang menggunakan kritik sastra feminis. Penelitian ini juga menggunakan datadata penunjang dari berbagai sumber, yaitu internet dan media cetak yang berhubungan dengan permasalahan.
Analisis data menggunakan kajian kritik sastra feminis yang menganalisis tokoh wanita yang mengalami kekerasan gender dan kesetaraan gender. Tahap selanjutnya, melakukan interpretasi data dengan cara mengutip beberapa bagian novel, kemudian mendeskripsikannya.

\section{HASIL DAN PEMBAHASAN Gambaran Tokoh Wanita dalam No- vel Kapak}

Kehadiran tokoh pada suatu karya sastra merupakan hal yang penting dan menentukan. Karena tidak akan ada suatu cerita tanpa kehadiran dan gerak tokoh. Tokoh menunjukkan orang-orang yang ada dalam cerita serta menjelaskan bagaimana lukisan watak-watak dari para tokoh tersebut, misalnya pembauran antara kepentingan-kepentingan, keinginan, perasaan, dan prinsip-prinsip moral yang dimiliki tokoh (Stanton dalam Nurgiyantoro, 2000:176-178). Tokohtokoh wanita yang ditampilkan dalam novel Kapak sebagai berikut.

\section{Mika}

Mika merupakan istri seorang kepala perang yang bernama Mundus. Ia digambarkan sebagai seorang wanita yang memiliki fisik yang kuat karena telah melahirkan tiga belas orang anak, delapan orang anak meninggal karena bermacam penyakit dan hanya lima orang yang hidup. Bagi wanita di kalangan suku Asmat, melahirkan merupakan perjuangan antara hidup dan mati karena mereka harus melakukannya seorang diri tanpa pertolongan bidan dan dukun beranak. Proses melahirkan pun harus dilakukan di tengah hutan karena tidak boleh melakukannya di rumah karena bagi suku Asmat darah yang dikeluarkan oleh wanita yang melahirkan merupakan darah kotor yang dapat menimbulkan penyakit sampai kematian. 
... Tiba-tiba, kesunyian di hutan itu terpecah oleh jeritan menyayat kemudian menimbulkan gema yang bergaung. Tangis bayi mengoek-oek. Darah pun tertumpah di atas tapin. Orang Asmat, bahwa darah yang mengalir dari bagian paling rahasia seorang wanita yang melahirkan, akan menimbulkan penyakit dan kematian. Sebab itu, seorang wanita tak diperkenankan untuk melahirkan di dalam rumah, darah itu akan mendatangkan bencana bagi orang yang tinggal di dalamnya. Adalah suatu keharusan, bahwa seorang wanita yang hendak melahirkan, mesti pergi ke tengah hutan (Linggarsari, 2005:9-10).

Selain itu, Mika juga seorang wanita pemberani. Ia tidak tinggal diam ketika diperlakukan tidak adil oleh suaminya yang mengawini dan berselingkuh dengan wanita lain. Perlawanan pun dilakukan terhadap tokoh wanita yang bernama Upra dan Ero yang telah dinikahi Mundus hanya demi memperoleh kayu gaharu.

... Beberapa saat setelah Mundus berlari, suasana rumah itu menjadi hening ... Sementara Mika menjadi nyalang, ia menatap Upra dengan bara dendam yang menyala-nyala. Setelah sebuah pekikan yang mengiris, ia pun menerkam Upra. Keduanya berguling di lantai papan, saling memukul, mencakar, dan mencaci maki, disaksikan empat anak yang menjerit ketakutan tanpa daya untuk melerai (Linggarsari, 2005:26)

... Ero berdiri dengan kacau untuk membenahi pakaiannya yang tercerai berai. Tapi sebelum pakaiannya kembali rapi seperti semula wanita itu segera merasa ada sebuah pukulan berat menghantam kepalanya. Refleks, Ero berbalik untuk membela diri. Tapi usahanya sia-sia, pukulan itu kembali menghantam tengkuk kemudian kemaluannya. Ero menjerit kemudian terkapar dalam keadaan setengah telanjang (Linggarsari, 2005:80)
Sebagai seorang wanita pemberani, Mika memiliki dendam pada suaminya, Mundus, yang sering berbuat kekerasan kepada dirinya. Semua itu dapat dibalasnya pada suatu upacara adat yang memberikan pembelaan kepada wanita karena selalu dianiaya suaminya.

... Kesempatan pertama untuk menghajar Mundus telah datang bagi Mika. Wanita itu menginjak-injak tubuh Mundus dengan kalap. Telinga Mika seakan tuli oleh sakit hati yang terpendam bertahun-tahun lamanya, sehingga jeritan panjang dari mulut Mundus tidak lagi terdengar. Ketika dengan sepenuh tenaga Mika mengayunkan parang, maka jeritan panjang dari mulut Mundus segera berubah menjadi isak tangis. Sementara luka di punggung yang menganga mulai mengucurkan darah. Cairan merah yang terus mengucur dan tergenang di lumpur itu perlahan-lahan mulai meredakan kemarahan Mika. Wanita itu telah mengambil haknya untuk memelihara keseimbangan, setelah penganiayaan yang dilakukan Mundus berulang kali (Linggarsari, 2005:41)

\section{Yemnen}

Yemnen merupakan anak perempuan Mika dan Mundus yang mulai beranjak dewasa. Kedewasaan terlihat ketika ia mulai memahami ayahnya mempunyai istri lagi selain ibunya. Ia mulai menghibur ibunya dengan mengatakan bahwa hal itu sudah biasa dialami wanita suku Asmat. Walaupun di satu sisi-sebagai seorang wanita-ia merasa dikhianati dan tidak dihargai lagi.

Yemnen sebagai anak tertua sudah cukup mengerti arti semua ini. Bukan hal baru di kampung ini, bahwa seorang anak laki-laki dapat memiliki lebih dari satu istri, khususnya bila ia memiliki kedudukan penting dalam adat. Mundus adalah kepala perang, ia berhak memiliki dua, bahkan empat istri sekaligus. Yemnen memandangi mamaknya dengan mata tergenang. Ketika 
gadis itu bersimpuh di depan Mika, maka air matanya tak terbendung lagi. "Diamlah mamak. Begini sudah kitorang pu adat," Yemnen mencoba menghibur mamaknya. Kata-kata itu bukan membuat Mika terdiam, bahkan pecah sudah tangisnya (Linggarsari, 2005:22)

Pertengkaran yang sering terjadi antara Mika dan Mundus membuat Yemnen tidak betah di rumah. Yemnen kemudian melarikan diri ke rumah pacarnya, Simon. Keluarga Simon akhirnya dapat menerima kehadiran Yemnen walaupun mereka meragukan Mundus yang akan mencari anaknya karena posisinya sebagai kepala perang. Sebagai kepala perang ia merasa tidak dihargai karena bagi suku Asmat anak kepala perang tidak boleh mendapat perlakuan kasar dari siapa pun. Akhirnya ia menyusul Yemnen ke rumah orang tua Simon.

\section{Bunafi}

Bunafi merupakan tokoh wanita yang mendapat kekerasan fisik dari suaminya, Donatus, karena dianggap telah melakukan perselingkuhan dengan laki-laki lain yang bernama Jirimo. Kekerasan fisik itu terlihat pada kutipan berikut.

... "Kau perempuan sundal, kau pergi ke bevak dengan Jirimo dan berlaku macam laki-bini. Terkutuklah engkau! Engkau tak pantas lagi menginjak rumah ini! Enyah koe, perempuan sundal!" suara Donatus terdengar bagai guruh yang menggelegar. ... Setelah itu kaki dan tangan Donatus terayun. Jerit kesakitan perempuan yang teraniaya disusul suara meraung anak-anak yang ketakutan terdengar bagai serangkaian mimpi buruk di telinga Yuwero (Linggarsari, 2009:51)

... "Kitorang masih sepupu, tidak pernah berbuat gila. Kubunuh kau!" sebuah tendangan Donatus menyepak Bunafi, sehingga wanita itu terpelanting keluar dari pintu rumah kemudian terjerembab ke dalam lumpur dengan muka kehitam-hitaman (Linggarsari, 2005:52)

\section{Dokter Astrid}

Dokter Astrid seorang wanita berprofesi dokter yang bekerja di wilayah Asmat yang membantu mengobati masyarakat terutama kaum wanitanya yang banyak terjangkit penyakit kelamin karena kurangnya pengetahuan dan akibat penindasan yang dilakukan oleh suaminya. Ia seorang wanita pemberani dan peduli untuk memperbaiki nasib kaum wanita yang berada di sekitar lingkungan tempatnya bertugas tersebut.

"Saya bersyukur bisa bekerja di wilayah Asmat dalam waktu yang cukup lama. Saya cuma menaruh belas kasihan kepada kaum wanita di sini. Dalam banyak kasus mereka selalu menjadi korban. Suatu saat saya akan menulis buku tentang wanita Asmat," dokter Astrid membuang pandang jauh-jauh, seakan tengah merekam seluruh penderitaan wanita Asmat (Linggarsari, 2009:117).

\section{Perspektif Gender dalam Novel $\mathrm{Ka}$ - pak}

Gender dibentuk berdasarkan konstruksi sosial yang erat kaitannya dengan masalah kultural, norma, dan nilai-nilai yang dianut oleh masyarakat. Setiap kelompok masyarakat memiliki konstruksi sosial yang berbeda-beda dalam memandang posisi kaum laki-laki dan perempuan sehingga akan terus berubah dan berkembang sesuai dengan peradaban yang membentuknya. Problem gender yang ditemukan dalam novel Kapak ini adalah ketidakadilan gender dan kesetaraan gender.

\section{Ketidakadilan Gender}

Ketidakadilan gender merupakan bentuk ketimpangan dalam sistem patriarkat yang menganggap posisi perempuan lebih lemah daripada laki-laki. 
Perempuan hanya sebagai kanca wingking 'teman belakang' atau dalam istilah bahasa Jawanya swarga nunut neraka katut (Fakih 2003:12). Kelemahan yang dimiliki wanita ini dimanfaatkan laki-laki untuk melakukan kekerasan terhadap perempuan seperti poligami, pemukulan, perselingkuhan dan bahkan pembunuhan. Manifestasi ketidakadilan gender yang ditemukan dalam novel Kapak ini adalah subordinasi dan kekerasan.

\section{Subordinasi}

Subordinasi merupakan suatu keadaan saat seseorang atau kelompok tertentu dianggap tidak penting di dalam pengambilan keputusan atau dianggap lebih rendah kedudukannya dibandingkan dengan yang lain (Fakih, 2013:14). Dalam novel Kapak, ditemukan kehidupan wanita suku Asmat yang cenderung disubordinasikan karena aturan adat. Dalam aturan adat suku Asmat, terdapat budaya patriarkat yang menganggap wanita lebih rendah kedudukannya dari laki-laki. Wanita dianggap rendah karena tidak dapat melepaskan diri dari kesewenangan laki-laki, kecuali anak perempuan kepala perang. Dalam budaya Asmat, wanita yang bukan anak kepala perang tidak boleh membantah apa yang dilakukan kaum pria terhadapnya, seperti kekerasan fisik dan kekerasan psikis (menikahi wanita lain).

Setelah seminggu peristiwa itu berlalu, bekas kemarahan Mundus masih menyisakan bentuk. Di kampung ini wanita memang selalu mengalami nasib yang malang. Mereka tak pernah dapat melepaskan diri dari kesewenangan laki-laki, kecuali anak perempuan kepala perang (Linggarsari, 2005:30)

Tokoh Mika tersubordinasi karena tidak bisa melawan budaya patriarkat yang melekat pada diri Mundus. Selain itu, Mika tidak boleh membantah apa yang dikatakan dan dilakukan Mundus terhadapnya karena ia adalah seorang pimpinan perang pada kaumnya. Seorang pimpinan perang dianggap sebagai orang yang paling tinggi kedudukannya di dalam suku Asmat.

Karena dianggap rendah, wanita sering dijadikan korban balas dendam atas perbuatan yang pernah dilakukan sesama pihak laki-laki. Hal ini terlihat ketika tokoh Yuwero ingin membalas dendam terhadap tokoh Jimiro, yang telah membunuh bapaknya (Mundus) dan pamannya (Donatus), dengan membunuh ketiga istri Jimiro. Ia menganggap wanita di kampungnya itu adalah makhluk yang lemah sehingga dengan mudah dapat mencelakakannya.

Kematian Donatus dan Mundus adalah pukulan telak bagi Yuwero, terlebih karena pembunuhan itu dilakukan oleh orang yang sama, Jimiro.

\begin{abstract}
Yuwero kemudian teringat kepada tiga istri Jimiro, bukankah wanita di kampung ini adalah makhluk yang lemah yang mudah terpedaya. Mereka tak akan mampu melawan, bila seorang pemuda kurus kecil sekalipun menyerangnya (Linggarsari, 2005:131).
\end{abstract}

Kalau saja Jimiro tak berniat mengambil Mika sebagai istri, barangkali masalahnya akan menjadi lain. Yuwero menimbang-nimbang dalam waktu yang cukup lama, sampai hari yang naas itu tiba. Yuwero tak pernah mencatat kapan kala itu ketika diam-diam ia membuntuti tiga istri Jimiro yang tengah pergi ke tengah hutan ... Beberapa detik kemudian, dendam pun berbicara. Kapak itu terayun dengan cepat, seorang korban jatuh (Linggarsari, 2005:131).

Subordinasi juga terlihat saat kaum laki-laki meremehkan kaum wanita dengan cara melakukan perselingkuhan dan menikahi wanita lain. Laki-laki bebas bergaul dengan wanita lain, baik di depan maupun di belakang istrinya. 
Mundus, suaminya Mika, digambarkan telah menikahi wanita lain yang bernama Upra dan Ero. Mereka wanita muda yang menginginkan kayu gaharu dari Mundus. Sebagai balas jasa, mereka harus rela dinikahi Mundus.

Raungan Mika telah berubah menjadi rintihan ketika Mundus dan Upra memasuki rumah secara beriringan. ... Wanita berambut lurus itu diam-diam telah mengobarkan api cemburu di dalam dadanya. Ia dapat mengamati setiap gerak-gerik wanita itu, juga manakala mereka, Ero dan Mundus saling mengerjapkan mata kemudian menghilang diam-diam ke dalam hutan (Linggarsari, 2005:78).

Tidaklah sulit bagi Mika untuk mengikuti jejak Mundus. Semak-semak yang tersibak dan gemersik ranting patah adalah sebuah petanda yang cukup mendirikan bulu roma. Tapi Mika masih sanggup menahan diri. Wajah perempuan itu memerah saga, ia berdiri kaku di balik semak-semak tanpa sepatah kata pun keluar dari mulutnya. Sepasang telinganya masih bekerja dengan cukup baik, sehingga ia dapat merekam seluruh peristiwa atas diri Ero dan Mundus (Linggarsari, 2005:79)

\section{Kekerasan}

Kekerasan adalah serangan atau invasi terhadap fisik maupun integritas mental psikologi seseorang. Salah satu bentuk kekerasan terhadap jenis kelamin tertentu yang disebabkan oleh prasangka gender disebut gender related-violence (Fakih, 2013:17). Kekerasan dibagi atas kekerasan psikologi dan kekerasan fisik

Kekerasan psikologi terlihat bagaimana perbuatan pria yang bebas menikahi wanita lain dan melakukan perselingkuhan. Kekerasan psikologi ini tidak menghargai kaum wanita karena dapat merugikan wanita. Kaum laki-laki dapat mengawini atau sekadar melepaskan hasrat seksnya dengan beberapa orang wanita, baik dari kaumnya sendiri maupun dari luar kaumnya.

Kekerasan psikologi ini juga terlihat dalam ketidakberdayaan wanita yang dimanfaatkan kaum laki-laki dengan membawa dua sampai tiga istri dalam satu rumah. Dalam novel Kapak hal ini diperlihatkan oleh Mundus yang membawa wanita lain yang telah dikawininya ke rumah Mika. Mika sebagai istri pertama tidak berdaya melakukan perlawanan terhadap perilaku tokoh Mundus. Pertengkaran pun sering terjadi di antara mereka, tetapi Mundus tetap bersikeras akan membawa wanita itu tinggal di rumah bersama mereka.

Keesokan harinya Yuwero terjaga dengan suara hentakan, sumpah serapah, bunyi tamparan, dan isak tangis dari mulut Mika. Yemnen, Yalean, Tukan, dan Wenen ikut terjaga karenanya. Hiruk pikuk itu bukan untuk yang pertama kali terjadi, tapi sudah berulang kali, bahkan sudah menjadi bagian dari kehidupan rumah ini.

"Kalau perempuan itu tinggal di sini, aku akan pergi," demikian suara Mika di sela-sela isak tangisnya (Linggarsari, 2005:21)

Kekerasan fisik yang dialami tokoh wanita terlihat seperti beratnya beban kerja dan pemukulan yang dilakukan oleh kaum laki-laki. Kekerasan dalam pembagian beban kerja terlihat ketika mereka sudah menikah. Wanita harus menyelesaikan semua pekerjaaan sebelum suami-suami mereka bangun. Mereka melakukan pekerjaan menangkap ikan dengan cara mengangkat jaring. Sore harinya mereka harus mengambil kayu bakar di hutan dan mengangkatnya sendiri pulang ke rumah. Hampir semua pekerjaan rumah tangga dilakukan oleh wanita. Kaum laki-laki merasa dirinya seorang yang kuat karena pekerjaannya menebang kayu dan membuat ukiran. Ini menunjukkan bahwa suku Asmat 
masih tetap mempertahankan budaya patriarkat yang masih menganggap lakilaki adalah seorang yang kuat dan perkasa serta menganggap wanita adalah kaum yang lemah. Kelemahan perempuan inilah yang dimanfaatkan laki-laki untuk melakukan kekerasan fisik terhadap perempuan, seperti tamparan, pukulan, tendangan, cengkeraman, dan injakan. Kekerasan fisik dialami tokoh Mika. Kekerasan fisik terhadap Mika dilakukan oleh Mundus karena Mika menentang dan menolak keinginan Mundus yang berniat membawa tokoh Upra untuk tinggal di rumahnya.

Mundus segera menginjak Mika dengan kakinya yang kekar kemudian menghujaninya dengan pukulan berulang kali. Hening malam pun segera terobek oleh suara melolong berkepanjangan disusul jerit ketakutan anak-anak. Mereka, Yalean, Tuka, Wenen, dan Yuwero, masih terlalu kecil untuk menyaksikan penganiayaan ini. Ibu yang telah melahirkan mereka kini terkapar dengan muka lebam dan mulut mengucurkan darah. Serentak, mereka merubung Mika dengan bersimbah air mata.

"Dengar Mika, tak seorang pun di rumah ini dapat memukul Upra. Tak seorang pun. Bila kamu melawan, aku tak segan-segan akan membunuhmu!" Demikian Mundus mengancam (Linggarsari, 2005:28)

Bentuk lain kekerasan fisik yang dilakukan Mundus terhadap Mika terlihat pada kutipan berikut.

Mundus mencengkeram pundak Mika kuat-kuat kemudian menariknya sedemikian rupa sehingga wanita itu terpaksa meloncat ke dalam perahu Mundus dengan tulang kering membentur dinding perahu. Mika terpekik. Dan jerit kesakitan yang diselingi isak tangis kembali bergema di sepanjang aliran sungai, karena Mundus terus-terus menendang dan memukuli Mika sampai mereka tiba di perkampungan.
Jerit tangis itu telah mengundang seisi kampung untuk menghambur keluar, melihat apa gerangan yang terjadi. Kemudian tampaklah pemandangan yang biasa menimpa kaum wanita di kampung ini (Linggarsari, 2005:33).

"Mika! Binatang koe!" Mundus menyepak Mika dengan sebuah tendangan hingga wanita itu terpaksa melepaskan cengkeraman di leher Upra kemudian terjerembab di sudut ruangan dengan tulang rusuk seakan remuk (Linggarsari, 2005:28).

\section{Kesetaraan Gender}

Untuk melawan ketidakadilan gender ini Dewi Linggarsari dalam novel Kapak juga mengungkapkan kesetaraan gender melalui tokoh wanitanya. Kesetaraan gender merupakan bentuk pembebasan kaum wanita dari kebodohan, kemiskinan, dan penindasan kaum laki-laki. Kesetaraan gender memperlihatkan kesamaan kondisi bagi laki-laki dan perempuan untuk memperoleh kesempatan dan hak-haknya sebagai manusia agar mampu berperan dan berpartisipasi dalam kegiatan politik, ekonomi, sosial, budaya, pendidikan, serta kesamaan dalam menikmati hasil pembangunan. Ini merupakan salah satu bentuk perjuangan kaum feminis untuk memperjuangkan haknya agar setara dan disejajarkan dengan kaum laki-laki. Bentuk kesetaraan gender yang ditemukan dalam novel Kapak ini adalah adanya bentuk perlindungan dan persamaan hak untuk wanita. Selain kekerasan yang biasanya dilakukan kaum laki-laki terhadap wanita, dalam novel ini digambarkan pula sosok wanita yang dapat melakukan kekerasan terhadap laki-laki. Selain itu, pekerjaan yang biasanya dilakukan oleh kaum laki-laki, wanita pun bisa mengerjakannya. Ini memperlihatkan kesamaan kondisi bagi wanita untuk memperoleh hak-haknya sebagai wanita. Kesetaraan gender ini terlihat dengan adanya aturan adat yang 
melindungi kaum wanita dan pendidikan bagi kaum wanita.

\section{Adanya Aturan Adat yang Melindungi Wanita}

Tokoh wanita dalam novel Kapak dapat melawan budaya patriarkat pada sebuah upacara adat pemberkatan rumah bujang ${ }^{2}$. Pada saat itu, wanita bebas melakukan tindak kekerasan terhadap suaminya sebagai aksi balas dendam terhadap kekerasan yang selama ini dialaminya.

Diam-diam Mundus mengeluh ... Ia menyadari, bahwa adat suku Asmat pada saatnya akan memberikan pembelaan kepada istri-istri setelah bertahun lamanya mereka dianiaya para suami. Pemberkatan rumah bujang itu berarti, bahwa saat itu akan segera tiba. Dan Mundus, tak dapat lagi mengelak. Ia harus menerima pembalasan setelah perbuatan aniaya yang berulang kali terhadap Mika (Linggarsari, 2005:42).

Dengan adanya upacara adat ini wanita Suku Asmat merasa adat telah memberikan pembebasan terhadap kaum wanita dari penindasan kaum laki-laki walaupun tidak selamanya itu bisa dilakukan.

... Yowero menyaksikan semua ini dalam sebuah proses yang ia sendiri tak sepenuhnya menyadari. Tapi nalar kebocahannya cukup mampu untuk menggoreskan sebuah catatan. Bahwa wanita menjadi pemberani karena perlindungan adat. Tanpa adanya adat, maka mereka adalah makhluk yang lemah yang mudah dianiaya (Linggarsari, 2005:44)

Selain itu, adat juga melindungi wanita anak kepala perang. Adat tidak mengizinkan satu orang pun melakukan kekerasan terhadap wanita anak kepala perang meskipun itu suaminya sendiri.
Setelah satu minggu peristiwa itu berlalu, bekas kemarahan Mundus masih menyisakan bentuk. Di kampung ini wanita selalu mengalami nasib yang malang. Mereka tak pernah dapat melepaskan diri dari kesewenangan lakilaki, kecuali, anak perempuan kepala perang.

Tiba-tiba, membersit seulas senyum di bibir wanita itu. Mika teringat kepada dua anak perempuannya, Yemnen dan Tuka. Mereka adalah anak kepala perang. Kelak, suami-suami mereka tak akan dapat memperbudaknya, karena kedudukannya itu. Sebaliknya, suamisuami itu bisa diperlakukan sebagai budak. Perlahan-lahan hati wanita itu menjadi damai (Linggarsari, 2005:30)

\section{Pendidikan untuk Kaum Wanita}

Bentuk kesetaraan gender lain yang dapat ditemukan dalam novel Kapak adalah partisipasi wanita dalam pendidikan. Dengan pendidikan diharapkan wanita dapat berguna sehingga dapat mempertahankan hak-haknya dalam menentang sistem budaya patriarkat yang ada di lingkungannya. Selain itu, wanita bukanlah makhluk yang lemah, wanita juga dapat melakukan pekerjaan seperti yang dilakukan laki-laki sehingga berdaya guna bagi lingkungannya.

Kesetaraan gender ini digambarkan oleh tokoh wanita bernama Astrid. Ia seorang dokter yang sangat peduli dengan kondisi wanita yang ada di sekitarnya. Kepeduliannya terlihat ketika ia membantu mengobati penyakit seksual yang dialami wanita karena tindakan kekerasan yang dilakukan suaminya.

Dokter Astrid terpaku di VK, ia harus berhadapan dengan Ibu Partus dalam kondisi vagina yang telah compangcamping. Sipilis itu telah mencapai stadium paling parah membentuk bungabunga kol (kondilomata lata). Dari mana wanita Asmat ini terjangkit penyakit kelamin? Dokter wanita itu menarik nafas panjang ... Tentu, ia tak perlu bersusah payah untuk mendapatkan 
jawaban. Komoditi gaharu yang kian marak, plasma-plasma yang bermunculan, para pencari kayu yang membanjir, kemudian PSK-Pekerja Seks Komersial-tentunya sudah menjadi lebih dari sekadar jawaban. Satu hal yang tak terduga adalah, bahwa penyakit menular yang dibawa para PSK itu akhirnya menjalar kepada orang Asmat sebagai penduduk asli, dan ibu-ibu sebagai pihak pasif yang dapat tertular selalu menjadi korban. Ibu Partus yang tengah mengerang, memperjuangkan kelahiran bayi itulah buktinya (Linggarsari, 2005:103)

Kepeduliannya terhadap wanita juga diperlihatkan ketika ia harus mencoba mengungkap sebuah kasus pembunuhan yang korbannya adalah wanita suku Asmat. Kejadian itu terjadi di sebuah desa yang sangat terpencil, yaitu Desa Buetkuar. Desa Buetkuar merupakan daerah yang paling terpencil karena harus ditempuh melalui Sungai Asuwetsy dengan menggunakan speed boat.

Dokter Astrid terdiam, ia tak lagi bertanya atau berkata. Wanita itu tenggelam dalam sebuah pemahaman yang sulit dicerna, tapi tak mampu menolaknya. Berulang kali ia berhadapan dengan kasus mengerikan yang menimpa perempuan pada suku ini, manakala mereka mesti jatuh sebagai korban (Linggarsari, 2005:110)

Selain itu dokter Astrid juga merupakan wanita yang memiliki keberanian. Keberaniannya terlihat ketika ia harus melakukan visum terhadap mayat kasus pembunuhan yang dialami seorang wanita. Ini memperlihatkan bahwa wanita juga memiliki keberanian seperti yang dimiliki laki-laki. Akibatnya ia bisa berbuat untuk kepentingan banyak orang tanpa dihalangi oleh kaum laki-laki.

Bau busuk menyengat hidung. Dokter Astrid dan Mantri Yusa telah menggunakan masker, sehingga dapat melindungi diri dari bau yang menyengat itu. Sementara Letnan Tambunan dan Sersan Effendi segera melilitkan jaket pada seputar hidung. Untuk sekian kalinya mereka harus berhadapan dengan tragis kasus pembunuhan dan kekuatan hati selalu menjadi jawaban. Demikianlah tugas mereka.

Dokter Astrid bekerja dengan profesional. Sebagai seorang wanita diam-diam hatinya teriris, tapi sebagai seorang dokter ia harus menyelesaikan tugas ini dengan sebaik-baiknya. Dokter itu menyerahkan buku visum dan alat tulis kepada Mantri Yusa kemudian menggunakan sarung tangan (Linggarsari, 2005:114).

\section{SIMPULAN}

Dari uraian di atas dapat disimpulkan bahwa perspektif gender yang terdapat dalam novel Kapak karya Dewi Linggarsari adalah adanya ketidakadilan gender dan kesetaraan gender yang dialami oleh tokoh-tokoh wanitanya Mika, Yemnen, dan dokter Astrid. Ketidakadilan gender terlihat adanya subordinasi dan tindakan kekerasan terhadap tokoh wanita Yemnen dan Mika. Subordinasi ini terjadi karena adanya budaya patriarkat yang masih terdapat pada masyarakat di wilayah Asmat yang menganggap wanita lebih rendah kedudukannya daripada laki-laki. Wanita dianggap rendah karena tidak dapat melepaskan diri dari kesewenangan laki-laki, kecuali anak perempuan kepala perang. Di dalam budaya Asmat kedudukan wanita yang bukan anak kepala perang tidak boleh membantah apa yang dilakukan kaum pria terhadapnya, akibatnya wanita Asmat mengalami kekerasan psikologi dan fisik. Kekerasan psikologi terlihat dalam ketidakberdayaan wanita yang dimanfaatkan kaum laki-laki dengan membawa dua sampai tiga istri dalam satu rumah. Hal ini diperlihatkan tokoh Mundus dengan membawa seorang wanita yang bernama Upra yang telah dikawininya ke rumah Mika istri pertamanya. 
Sementara itu, kekerasan fisik terjadi karena mereka menganggap laki-laki adalah seorang yang kuat dan perkasa, sedangkan wanita adalah kaum yang lemah. Kelemahan perempuan inilah yang telah dimanfaatkan laki-laki untuk melakukan kekerasan berupa tamparan, pukulan, tendangan, cengkeraman, dan injakan terhadap tokoh wanita yang bernama Mika.

Sementara itu, kesetaraan gender yang ditemukan dalam novel Kapak ini menunjukkan adanya persamaan hak bagi kaum wanita yang bisa menghindarkannya dari ketidakadilan gender. Ketidakadilan gender ini diperlihatkan dengan adanya aturan adat yang melindungi wanita dan pendidikan untuk wanita. Dengan adanya upacara adat yang terdapat dalam budaya Asmat kaum wanita bisa melawan budaya patriarkat yang menganggap mereka sebagai makhluk yang lemah. Pada upacara adat ini wanita bebas melakukan tindak kekerasan terhadap suaminya sebagai aksi balas dendam terhadap perilaku suaminya selama ini terhadap dirinya. Selain itu, dengan pendidikan diharapkan wanita dapat menentang sistem budaya patriarkat yang ada di lingkungannya dengan memperlihatkan adanya persamaan hak antara laki-laki dan wanita. Dokter Astrid yang ditampilkan dalam novel ini menunjukkan bahwa wanita bukanlah makhluk lemah yang hanya bisa jadi korban kekerasan laki-laki, tetapi wanita juga makhluk yang kuat dan pemberani. Ia ingin membantu memperbaiki nasib kaum wanita yang berada di lingkungannya dengan cara mengobati penyakit kelamin yang dialami karena kekerasan dari suaminya.

1. Makalah ini pernah dipresentasikan di The $23^{\text {rd }}$ HISKI Conference on Literature "Literature and Nation Character Building", Banjarmasin, 6-9 November 2013.
2. Suku Asmat memiliki rumah adat yang bernama JEW/JE (Rumah Bujang) yang panjangnya sampai 25 meter. Sampai sekarang masih dijumpai rumah tradisional ini jika berkunjung ke Asmat pedalaman. Rumah Bujang ini merupakan tempat untuk membicarakan program pembangunan kampung, pesta budaya, dan perkawinan di mana seluruh elemen masyarakat hadir untuk membicarakan, menyepakati, dan memutuskannya. Selain itu JEW juga merupakan tempat tinggal bagi kaum muda laki-laki dan kaum tua-tua sebagai tempat untuk belajar menjalankan kehidupan sehari-hari serta tempat untuk belajar budaya, ukiran, dan normanorma adat (Astuti, 2014:12).

\section{DAFTAR PUSTAKA}

Anshori, D. 1997. Membincangkan Feminis. Bandung: Pustaka Hidayah.

Astuti, Wahyu Puji. 2014. "Gambaran Gangguan Identitas Gender pada Laki-Laki Suku Asmat”. Skripsi. Jakarta: Fakultas Psikologi Universitas Yarsi.

Endraswara, Suwardi. 2008. Metodologi Penelitian Sastra: Epistemologi, Model, Teori, dan Aplikasi. Yogyakarta: FBS Universitas Negeri Yogyakarta.

Fakih, Mansour. 2003. Feminis dan Hegemoni Maskulinitas. Yogyakarta: Pustaka Pelajar.

------. 2013. Analisis Gender dan Transformasi Sosial. Yogyakarta: Pustaka Pelajar.

Linggasari, Dewi. 2004. Yang Perkasa Yang Tertindas, Potret Hidup Perempuan Asmat. Yogyakarta: Bigraf Publishing.

-------. 2005. Kapak. Yogyakarta: Kunci Ilmu.

-------. 2009. “Perempuan Asmat Harus Berjuang". Tabloid Jubi, 16 Februari 2009, hlm. 15.

Moleong, Lexy J. 2002. Metode Penelitian Kualitatif. Bandung: Remaja Rosda Karya.

Nugroho, Riant. 2008. Gender dan Strategi Pengarusutamaannya di Indonesia. Yogyakarta: Pustaka Pelajar. 
Nurgiyantoro, Burhan. 2000. Teori Pengkajian Fiksi. Yogyakarta: Gadjah Mada University Press.

Prambudi, Anas. 2011. "Subordinasi dalam Bias Gender pada Empat Cerpen Kumpulan Cerpen KOMPAS Pilihan 1970-1980-an: Dua Kelamin bagi Midin". Skripsi. Jakarta: Fakultas Ilmu Budaya, Universitas Indonesia.
Sugihastuti dan Suharto. 2005. Kritik Sastra Feminis, Teori, dan Aplikasinya. Yogyakarta: Pustaka Pelajar.

Sugihastuti dan Itsna Hadi Saptiawan. 2007. Gender dan Inferioritas Imferioritas Perempuan Praktik Kritik Sastra Feminis. Yogyakarta: Pustaka Pelajar. 